DOI: $10.19195 / 0137-1134.113 .9$

\author{
MICHAŁ RACZKOWSKI
}

Uniwersytet Warszawski

\title{
HOLDING JAKO PRACODAWCA? \\ PROBLEMY INDYWIDUALNEGO PRAWA PRACY W GRUPIE SPÓŁEK
}

\begin{abstract}
Abstrakt: Rosnąca rola grup przedsiębiorstw we współczesnej gospodarce staje się wyzwaniem dla tradycyjnej koncepcji pracodawcy. Z racji że holding de lege lata nie może być traktowany jako pracodawca, należy poszukiwać innych rozwiązań problemów pojawiających się w strukturach wielopodmiotowych. Obowiązujące przepisy, z bezpośrednim lub pośrednim wsparciem art. 8 kodeksu pracy, pozwalają na minimalizację niektórych aspektów nadużywania osobowości prawnej, takich jak wielokrotne zatrudnienie i niesprawiedliwa restrukturyzacja. Pozwalają one traktować różne działania różnych członków grupy tak, jakby były działaniem jedynego pracodawcy.
\end{abstract}

Słowa kluczowe: pracodawca, holding, grupa spółek, wielokrotne zatrudnienie

\section{UWAGI WPROWADZAJĄCE}

Badania dotyczące roli pracodawcy funkcjonującego w ramach struktur złożonych od wielu lat były i są prowadzone przez pracowników Wydziału Prawa i Administracji Uniwersytetu Wrocławskiego. Zorganizowana we Wrocławiu konferencja poświęcona pojęciu pracodawcy w stosunkach pracy i ubezpieczeń społecznych zatem dała znakomitą okazję do podzielenia się przez autora niniejszych uwag wątpliwościami z tego obszaru badawczego.

Problemy, które badano w ośrodku wrocławskim, koncentrowały się na działających w poprzednim ustroju kombinatach, zjednoczeniach (przedsiębiorstw i przemysłu), zrzeszeniach przedsiębiorstw, wspólnotach czy wielkich organizacjach gospodarczych ${ }^{1}$. Pozycja pracodawcy w kombinacie, będącym rodzajem

1 Wymieniam za: Z. Kubot, Wielkie organizacje gospodarcze a zakład pracy, [w:] Pracownicy i pracodawcy. Materiały XVI Zimowej Szkoły Prawa Pracy, red. W. Sanetra, Wrocław 1989, s. 124-125. 
złożonej osoby prawnej tworzącej zgrupowanie osób prawnych ${ }^{2}$, rodziła poważne wątpliwości w sferze prawa pracy, w szczególności w kwestii ustalenia kto pozostaje pracodawcą ${ }^{3}$. Zarówno kombinat, jak i jego zakłady dysponowały bowiem uprawnieniami i obciążone były obowiązkami jak pracodawca.

Grupowanie przedsiębiorców w dzisiejszej rzeczywistości gospodarczej i prawnej wymaga innego podejścia badawczego 4 . Zasadnicza różnica między ówczesnymi strukturami kombinatowymi a dziś funkcjonującymi holdingami tkwi w sposobie ich tworzenia. Pierwsze były tworzone administracyjnie, z wykorzystaniem norm prawnych, drugie tworzą się samodzielnie, z inicjatywy podmiotów wchodzących w skład holdingu ${ }^{5}$. O ile zatem źródłem funkcjonowania kombinatów były normy prawa administracyjnego, które wprost przewidywały istnienie takich jednostek i udzielały im kompetencji lub nakładały obowiązki, o tyle w wypadku holdingów prawo prywatne (cywilne i handlowe) nie przewiduje reguł ich tworzenia, funkcjonowania, nie nakłada także — co do zasady — szczególnych obowiązków na te struktury.

Wyjątkiem są wprowadzone do kodeksu spółek handlowych obowiązki informacyjne, nakazujące zgłaszanie stosunków dominacji (art. 6 k.s.h.), które stanowią podstawę powiązań w ramach grup spółek (holdingów). To z kolei wymaga zdefiniowania pojęcia dominacji, co czyni ustawodawca prawa prywatnego $\mathrm{w}$ art. 4 $\S 1$ pkt 4 k.s.h., wskazując liczne kryteria dominacji o charakterze kapitałowym i osobowym. Definicja stosunków dominacji — pośrednio konstytuująca grupę spółek - ma ograniczone znaczenie normatywne. Chodzi w niej przede wszystkim o ujawnienie istnienia relacji dominacji względem innych uczestników obrotu, a także ograniczenie możliwości obchodzenia przez spółki zakazów nabywania własnych akcji/udziałów 6 .

Poruszając się w obszarze prawa pracy, lepszym punktem odniesienia wydaje się jednak definicja grupy przedsiębiorstw zawarta w ustawie z dnia 5 kwietnia 2002 r. o europejskich radach zakładowych ${ }^{7}$. Służy ona nałożeniu na grupę przedsiębiorstw obowiązków o charakterze informacyjno-konsultacyjnym.

2 Tak A. Klein, Sytuacja prawna zakładów kombinatów obrocie uspołecznionym, [w:] Sytuacja prawna zakładów kombinatów, red. A. Klein, Wrocław 1982, s. 27; podobnie wyglądała sytuacja zjednoczeń, por. ibidem, s. 27-29.

3 Zob. J. Jończyk, Sytuacja zakładu pracy w kombinacie w świetle przepisów Kodeksu pracy, [w:] Sytuacja prawna..., s. 13-22.

4 Prezentuje je w odniesieniu do wielu aspektów działania holdingów Z. Kubot, zob. na przykład Rola spótki dominującej w sporze zbiorowym spółki zależnej, cz. I, PiZS 2014, nr 10; cz. II, PiZS 2014, nr 12.

5 Tak trafnie J. Okolski, W. Opalski, Uwagi na temat możliwości tworzenia organizacji koncernowych w Polsce, PUG 1987, nr 6, s. 145.

6 A. Szumański, [w:] S. Sołtysiński et al., Kodeks spótek handlowych. Komentarz, Warszawa 2004, komentarz do art. 4, Nb. 23, pkt 1.

7 Dz.U. z 2012 r. Nr 10, poz. 12 ze zm. (dalej: u.e.r.z.). 
Pod pojęciem grupy przedsiębiorstw ustawa rozumie przypadki, w których co najmniej dwóch przedsiębiorców pozostaje w relacji dominacji-zależności (art. 2 pkt 2 ustawy). Co więcej, pojęcie przedsiębiorcy zostało zdefiniowane nie tylko w art. $4 \S 1$ pkt 4 k.s.h., w którym mowa wyłącznie o spółkach. W art. 2 pkt 1 u.e.r.z. za przedsiębiorcę uznaje się osobę fizyczną, osobę prawną oraz niemającą osobowości prawnej spółkę prawa handlowego, która zawodowo we własnym imieniu podejmuje i wykonuje działalność gospodarczą, jak również działalność wy twórczą w rolnictwie w zakresie upraw rolnych oraz chowu i hodowli zwierząt, ogrodnictwa, warzywnictwa, leśnictwa i rybactwa śródlądowego. O ile z istoty osoba fizyczna nie może być podmiotem zależnym, o tyle może być ona podmiotem dominującym w grupie.

Także ten element, to jest władztwo podmiotu dominującego nad zależnym, znalazł się w art. 4 u.e.r.z. W pewnym uproszczeniu (na marginesie podobne kryteria wprowadza art. 4 § 1 pkt 4 k.s.h.) stosunek dominacji może mieć postać kapitałową (dysponowanie większością głosów na walnym zgromadzeniu/zgromadzeniu wspólników lub w zarządzie drugiej spółki kapitałowej) lub osobową (prawo powoływania większości członków zarządu lub rady nadzorczej podmiotu zależnego albo faktyczna unia personalna zarządów obu spółek). Stosunek zależności może także wynikać z umowy koncernowej (art. 4 ust. 1 in fine u.e.r.z., art. 7 k.s.h.).

Opisana regulacja służy — jak wskazano — nałożeniu na grupę przedsiębiorstw o zasięgu wspólnotowym obowiązku przekazania informacji i prowadzenia konsultacji z przedstawicielstwem pracowniczym niektórych jedynie spraw związanych z funkcjonowaniem grupy i jej oddziaływaniem na relacje zatrudnienia. Co do zasady - w innych obszarach, a w szczególności w ramach indywidualnego prawa pracy — ustawodawstwo pracy nie dostrzega natomiast skutków funkcjonowania pracodawcy w ramach złożonych struktur gospodarczych.

Nie chcąc tu powtarzać prezentowanych gdzie indziej uwag dotyczących motywów powstawania zgrupowań spółek (holdingów) oraz praktyki ich funkcjonowania $^{8}$, wypada stwierdzić, że samodzielność pracodawcy (spółki zgrupowanej) zostaje — przynajmniej w aspekcie ekonomicznym — zakwestionowana na rzecz konieczności jego mniej lub bardziej zaawansowanej współpracy z innymi pracodawcami (spółkami zgrupowanymi).

De lege lata natomiast stosunki pracy i stosunki z nimi powiązane są oceniane jedynie na płaszczyźnie pracownik-pracodawca niezależnie od tego, czy ów pracodawca funkcjonuje w obrocie gospodarczym samodzielnie, czy też we współpracy (w ramach grupy) z innymi podmiotami. Da się natomiast wyodrębnić obszary, w których istnienie powiązań z innymi podmiotami może osłabiać ochronne oddziaływanie norm prawa pracy.

${ }^{8}$ M. Raczkowski, Grupa spótek (holding) jako pracodawca, PiZS 2016, nr 7, s. 10. 


\section{OCHRONNA FUNKCJA PRAWA PRACY A RELACJE W GRUPIE SPÓŁEK}

Uregulowania prawa pracy co do zasady pełnią swą ochronną funkcję niezależnie od tego, czy pracodawca funkcjonuje samodzielnie, czy też w obrębie grupy. Niemniej jednak jego instytucje zakładają, że ochrony należy udzielać pracownikowi w stosunkach, jakie wiążą go z indywidualnym — skonkretyzowanym - pracodawcą 9 .

Wskazać można w związku z tym dwa zasadnicze obszary, w których oddziaływanie norm prawa pracy osłabia się w związku z występującą $\mathrm{w}$ grupach spółek wielopodmiotowością, a mianowicie:

1. równoległe pozostawanie pracownika w relacjach prawnych lub faktycznych z dwoma lub więcej podmiotami (pracodawcą i innymi podmiotami zgrupowanymi, w szczególności pomiotami dominującymi względem pracodawcy);

2. transfery pracowników między podmiotami grupy lub - w niektórych przypadkach - wykorzystywanie powiązań w grupie do rozwiązywania stosunków pracy, które w innym przypadku byłyby prawnie niedopuszczalne lub łączyły się z dodatkowymi obowiązkami.

Odnosząc się do pierwszej grupy przypadków, wypada zauważyć, że jest możliwe takie ukształtowanie stosunków prawnych między pracownikiem a pracodawcą i innymi podmiotami należącymi do grupy, które nie byłoby dopuszczalne $\mathrm{w}$ relacji wiążącej go wyłącznie $\mathrm{z}$ jednym pracodawcą ${ }^{10}$.

Za instytucję kluczową odnośnie do tego porównania uznać wypada regulację czasu pracy. Równoległe zatrudnienie pracownicze w dwóch lub więcej podmiotach grupy umożliwia zatrudnienie w rozmiarze znacznie przekraczającym normy czasu pracy (art. 129 k.p.), bez konieczności rekompensowania tego za pomocą wynagrodzenia nadliczbowego. W ten sam sposób pominąć można inne ograniczenia przewidziane unormowaniem czasu pracy (w szczególności względne i bezwzględne zakazy zatrudnienia w godzinach nadliczbowych). Równie ważne są aspekty prawa do odpoczynku, który — jeśli uwzględniany indywidualnie przez każdego z pracodawców zgrupowanych — może nakładać się na okres pracy u drugiego $z$ tych pracodawców.

$\mathrm{Z}$ regulacją czasu pracy — przynajmniej w części — powiązane są problemy równoległego zatrudnienia pracowniczego i niepracowniczego. Równoległe zatrudnienie cywilnoprawne może służyć obchodzeniu przepisów właśnie o pracy w godzinach nadliczbowych. Równoległe zatrudnienie niepracownicze wydaje się także służyć ograniczaniu należności publicznoprawnych ubezpieczenia społecznego. Nawiązywanie relacji cywilnoprawnych z podmiotami grupy innymi niż pracodawca może wreszcie służyć omijaniu innych ograniczeń, które spoczywałyby na pracodawcy względem pracownika (na przykład zabezpieczenie wekslowe

9 Wynika to w szczególności z oddziaływania zasady swobody umów, por. ibidem, s. 11-12.

10 Ibidem, s. 12-13. 
na mieniu podmiotu innego niż pracodawca, zasady zwrotu świadczeń z tytułu podnoszenia kwalifikacji zawodowych ujmowane w relacji z takim podmiotem, a nie z pracodawcą).

Nie mniej istotne niż stosunki prawne, w jakie pracownik może wchodzić z uczestnikami grupy, pozostają aspekty faktyczne wykonywania przez niego pracy na rzecz pracodawcy należącego do zgrupowania. Wchodzą tu w grę przypadki polecenia pracownikowi takiej pracy, która w istocie polega na faktycznym oddaniu pracownika do dyspozycji innego podmiotu. Nawet jednak jeśli nie dojdzie do tego rodzaju niedopuszczalnych sytuacji, wejście pracownika w relacje faktyczne z pracownikami innego pracodawcy należącego do zgrupowania rodzi prawne wątpliwości (na przykład konieczność zapewnienia bezpiecznych i higienicznych warunków pracy, ryzyko mobbingu lub niektórych postaci dyskryminacji, rozliczanie czasu pracy). Przekształcenia w obrębie grup mogą także służyć naruszaniu majątkowych interesów pracowników w zakresie przekraczającym ochronę przewidzianą $\mathrm{w}$ kwestii przypadków niewypłacalności pracodawcy.

Druga z wymienionych kategorii (transfery pracowników lub rozwiązywanie stosunków pracy), zarówno w grupie spółek, jak i poza nią, obejmuje transfery indywidualne i zbiorowe. Rozwiązanie stosunku pracy przez pojedynczego pracownika z pracodawcą należącym do zgrupowania i nawiązanie go u innego w świetle obecnego stanu prawnego - nie różni się niczym od jakiegokolwiek innego przypadku zmiany zatrudnienia między pracodawcami niepowiązanymi. Budzi to wątpliwości co najmniej w tych przypadkach, w których inicjatywa zakończenia zatrudnienia (i nawiązania nowego) wychodzi od pracodawców należących do grupy.

Sytuacja przedstawia się inaczej w wypadku transferów zbiorowych, które najczęściej mają za podstawę art. $23^{1}$ k.p. Norma ta gwarantuje trwałość stosunku pracy, a zatem wszystkich przysługujących pracownikowi uprawnień i nałożonych obowiązków, w szczególności stanowi o ciągłości zakładowego stażu pracy. Ale dominująca wykładnia art. $23^{1}$ k.p. obejmuje wyłącznie stosunek pracy z pominięciem klauzul autonomicznych.

Nie można, na koniec, pomijać przypadków transferów pracowników (indywidualnych lub zbiorowych), w których następstwie dochodzi do likwidacji nowego pracodawcy lub innego ograniczenia jego działalności, czego efektem staje się rozwiązanie stosunków pracy.

\section{GRUPA SPÓŁEK JAKO PRACODAWCA}

Nie da się zaprzeczyć, że wszystkie wymienione problemy są wynikiem wielopodmiotowości występującej w grupie spółek. Najprostszym rozwiązaniem wydawałoby się zredefiniowanie pojęcia pracodawcy, występującego w art. 3 k.p., w taki sposób, aby za pracodawcę uznawać nie tyle pojedynczy podmiot (osobę 
prawną lub tradycyjnie ujmowaną jednostkę organizacyjną), ile całą grupę. Teoretycznie nie musiałoby to nawet wymagać zmiany normatywnej, lecz jedynie wykładni tego przepisu i użytej w jego treści konstrukcji ,jednostki organizacyjnej”. Mogłaby ona obejmować nie tylko jednostki organizacyjne prawa publicznego czy tak zwane wewnętrzne zakłady pracy ${ }^{11}$, ale także grupę spółek ${ }^{12}$.

Pojęcie jednostki organizacyjnej (na przykład w świetle analizy J. Frąckowia$\mathrm{ka}^{13}$ ) cechuje się znacznym stopniem ogólności. Składają się na nie — w ocenie tego autora - takie elementy, jak nazwa, siedziba czy struktura organizacyjna. Jakkolwiek oprócz nich, a może przede wszystkim, Frąckowiak upatruje konieczności rozpoznania (określenia) jednostki organizacyjnej przez normy prawne, to pozostałe wskazane cechy tej konstrukcji można byłoby mutatis mutandis zastosować do holdingu. Da się wskazać jego nazwę (na przykład korzystając z prawno-podatkowej konstrukcji grupy kapitałowej, art. 1a ustawy z dnia 15 lutego 1992 r. o podatku dochodowym od osób prawnych, tekst jedn. Dz.U. z 2014 r. poz. 851 ze zm.). Ma on także strukturę organizacyjną, albowiem składa się z podmiotu dominującego i szeregu podmiotów zależnych. Trudnością byłoby natomiast wskazanie jego siedziby, albowiem nie ma on organu zarządzającego, którego siedziba decyduje w ostateczności (w braku regulacji ustawowej lub statutowej) o siedzibie osoby prawnej (art. 41 k.c.).

Fakt, że holding reprezentuje się przynajmniej niektórymi cechami jednostki organizacyjnej, pozwala rozważyć, czy grupa taka nie stanowi w całości specyficznej jednostki organizacyjnej. Rozwiązanie takie, jak zresztą podnoszono ${ }^{14}$, rodziłoby ogromną liczbę komplikacji w ujęciu zarówno teoretycznym, jak i praktycznym.

Po pierwsze, oderwanie podmiotowości pracodawcy od podmiotowości definiowanej $w$ innych gałęziach prawa rodzi kolosalne trudności systemowe. Od wielu lat i w wielu opracowaniach prezentuje te wątpliwości na tle tak zwanych wewnętrznych pracodawców Z. Hajn ${ }^{15}$. Grupa spółek nie dysponuje samodzielną podmiotowością prywatnoprawną, nie jest także co do zasady podmiotem prawa

11 Co stanowi tradycyjnie analizowany w literaturze dylemat nauki prawa pracy, zob. na przykład M. Gersdorf, Jeszcze w sprawie sporu o pojęcie pracodawcy, PiZS 1997, nr 2, s. 34 n.; Z. Hajn, Pojęcie pracodawcy po nowelizacji Kodeksu pracy, cz. I, PiZS 1997, nr 5, s. 20 n.; L. Kaczyński, W sprawie jednostki organizacyjnej jako pracodawcy, PiZS 1998, nr 5, s. 37 n.

12 M. Raczkowski, Powiazania kapitałowe pracodawcy a stosunek pracy, PiP 2009, nr 3, s. $66-71$.

13 J. Frąckowiak, Jednostka organizacyjna jako substrat osoby prawnej i ustawowej, [w:] Rozprawy prawnicze. Ksiega pamiątkowa prof. Maksymiliana Pazdana, red. L. Ogiegło, W. Popiołek, M. Szpunar, Kraków 2005, s. 903-904.

14 M. Raczkowski, Powiazania kapitałowe pracodawcy..., s. 70-71.

15 Zob. Z. Hajn, [w:] System prawa pracy, t. 2, red. G. Goździewicz, Warszawa 2017, s. 150 n.; oraz przedstawione w niniejszym tomie opracowanie, będące referatem konferencyjnym tego autora. 
publicznego ${ }^{16}$. Nie ma odrębnej podmiotowości w prawie ubezpieczeń społecznych. Wykreowanie jej podmiotowości w prawie pracy rodziłoby konsekwencje w wielu sferach podobne do tych, które wiążą się z pracodawcami wewnętrznymi - trudności w stosowaniu norm innych dziedzin prawa, których stosowania do pracodawcy nie da się uniknąć.

W szczególności trzeba zauważyć, że holding nie ma organu ani osoby zarządzającej, która w świetle prawa miałaby go reprezentować, co obejmowałoby w szczególności dokonywanie czynności w sprawach z zakresu prawa pracy (art. $3^{1}$ k.p.). Nie tylko więc nie można mu przypisać — tak jak tego wymagamy od jednostki organizacyjnej — siedziby, lecz wręcz zdolności do działań prawnych z wszelkimi tego konsekwencjami (nabywania praw, zaciągania zobowiązań, odpowiedzialności itp.).

Hipotezę o możliwości uznania holdingu za pracodawcę w ramach wykładni art. 3 k.p. uznaję za zweryfikowaną negatywnie ${ }^{17}$. De lege lata nie ma możliwości kwalifikowania holdingu jako pracodawcy w świetle art. 3 k.p. Zgadzam się zatem z wszystkimi autorami, którzy problem holdingowy uważali za niemożliwy do rozwiązania przez przypisanie $\mathrm{w}$ obecnym stanie prawnym funkcji pracodawcy czy to podmiotowi dominującemu w zgrupowaniu ${ }^{18}$, czy to całemu zgrupowaniu ${ }^{19}$. Wyraźnie przeciwko takiej interpretacji de lege lata opowiadają się P. Czarnecki ${ }^{20}$, Z. Kubot ${ }^{21}$ i Z. Hajn ${ }^{22}$.

\section{POMIJANIE PRAWNEJ ODRĘBNOŚCI CZŁONKÓW ZGRUPOWANIA W UJĘCIU DE LEGE LATA}

Brak możliwości uznania holdingu za pracodawcę nie oznacza, że w obecnym stanie prawnym nie istnieją instrumenty, które mogłyby przeciwdziałać niepo-

16 Takim wyjątkiem jest instytucja podatkowej grupy kapitałowej, która umożliwia na przykład wspólne rozliczenie dochodu spółek należących do grupy, co z kolei umożliwia uwzględnienie strat $w$ ramach takiego rozliczenia, wyłączenie obowiązku stosowania we wzajemnych rozliczeniach cen rynkowych czy prawo powołania się na interpretację podatkową wydaną dla reprezentanta grupy przez jej członków; więcej A. Mariański, Podatek dochodowy od osób prawnych. Komentarz, Warszawa 2012, uwaga 1 do art. 1a.

17 M. Raczkowski, Grupa spólek (holding)..., s. 13-15.

18 H. Lewandowski, Problemy prawa pracy zwiazane z restrukturyzacja przedsiębiorstwa, [w:] Człowiek, obywatel, pracownik. Księga jubileuszowa poświęcona profesor Urszuli Jackowiak, red. J. Stelina, A. Wypych-Żywicka, Gdańsk 2007, s. 152.

19 Ł. Pisarczyk, Ryzyko pracodawcy, Warszawa 2009, s. 175.

20 P. Czarnecki, Odpowiedzialność pracodawcy a rozwój struktur holdingowych, Warszawa 2014, s. 175.

21 Z. Kubot, Odcinkowa zdolność pracodawcza spótki dominujacej w grupie kapitałowej, PiZS 2014, nr 9, s. 20.

22 Z. Hajn, [w:] System prawa pracy..., s. 186-187. 
żądanym skutkom funkcjonowania grup spółek w sferze indywidualnego prawa pracy. Jak już wskazano, objawiają się one przede wszystkim w razie pozostawania pracowników w równoległych stosunkach pracy z pracodawcą lub pracodawcami należącymi do grupy albo też gdy pracownik jednego z podmiotów grupy wchodzi w relacje niepracownicze z innym członkiem grupy. Skutki niepożądane mogą także być efektem reorganizacji zatrudnienia dokonywanych w obrębie grup.

Mechanizmy, które pozwalają unikać tych skutków, powinno się w ocenie autora niniejszych uwag kwalifikować jako pomijanie prawnej odrębności członków zgrupowania. Zasadne wydaje się unikanie stosowanego przez niektórych autorów terminu „odpowiedzialność przebijająca" 23 jako nieoddającego istoty zagadnienia. Celem instrumentów przeciwdziałania nadużyciom w sferze stosunków pracy nie jest bowiem pociąganie do odpowiedzialności podmiotów innych niż pracodawca, lecz wręcz przeciwnie - przypisywanie pracodawcy skutków działań podejmowanych przez inne podmioty należące do grupy lub ich szeroko rozumianych funkcjonariuszy.

Do zastosowania ,przypisania” nie wystarcza także, by pracownik wchodził w wiele relacji zatrudnienia lub by dokonywano reorganizacji w obrębie grupy. Okolicznościom tym muszą towarzyszyć dodatkowe elementy świadczące o istnieniu stanu nadużycia osobowości prawnej ${ }^{24}$.

Przykładem nadużyć związanych z równoległym zatrudnieniem jest stan faktyczny sprawy zakończonej wyrokiem Sądu Najwyższego z dnia 5 listopada 2013 r., sygn. II PK 50/13. Pracodawca, podobnie jak inne spółki z jego grupy kapitałowej, zajmował się świadczeniem usług ochroniarskich. Z pracownikami - równolegle z nawiązaniem zatrudnienia pracowniczego - zawierano umowy-zlecenia. W ramach tych umów „rozliczano” ponadwymiarowy czas pracy pracowników. Zamiast wynagrodzenia z tytułu pracy w godzinach nadliczbowych wypłacano wynagrodzenie z umów-zlecenia. Nie występowało tu jednak czytelne rozdzielenie zadań wykonywanych w ramach każdej z umów. Zatrudnieni wykonywali pracę jako ochroniarze w tych samych obiektach. W skrajnych przypadkach ów podział stosunków zatrudnienia prowadził do stanu, w którym część (początek) zmiany w konkretnym dniu zatrudniony wykonywał jako pracownik, a kończył pracę już jako zleceniobiorca na rzecz innego podmiotu zatrudniającego.

Sąd Najwyższy w tym orzeczeniu dostrzegł możliwość traktowania tego rodzaju pracy jak pracy na rzecz pracodawcy, a nie na rzecz innych podmiotów grupy - a zatem jako wykonywaną w ramach stosunku pracy, a nie umów cywilnoprawnych. Nie odnosząc się do legalności tych ostatnich (co jak wskazano, byłoby ewentualnie możliwe, choć nie bez wątpliwości, na podstawie art. 83 k.c. czy art. $58 \S 1$ k.c.), najłatwiej przyjąć, że nie były one wykonywane, lecz re-

23 Tak na przykład P. Czarnecki, op. cit.

24 M. Raczkowski, Pomijanie prawnej odrębności członków holdingu w indywidualnym prawie pracy, PiZS 2016, nr 7, s. 15 n. 
alizowana przez pracowników praca była pracą na rzecz pracodawcy w ramach stosunku pracy. Była to więc praca w godzinach nadliczbowych, za którą pracodawca winien był wypłacić wynagrodzenie wraz z dodatkiem w rozumieniu art. 151 i następnych k.p.

Orzeczenie to pokazuje, że do pominięcia prawnej odrębności członków zgrupowania nie wystarczy powierzanie pracownikowi (zatrudnionemu) pracy w dwóch podmiotach. W stanie faktycznym widoczne były doskonale elementy nadużycia wielości uczestników zgrupowania. W ocenie autora niniejszych uwag w wypadku równoległego zatrudnienia o nadużyciu mogą świadczyć następujące, generalnie ujmowane okoliczności ${ }^{25}$ :

1. podział jednego zadania roboczego między dwie lub więcej więzi zatrudnienia ${ }^{26}$

2. przemieszanie sfer w zakresie reprezentacji - dokonywanie czynności prawnych i kierowanie procesem pracy przez te same osoby fizyczne reprezentujące różnych uczestników holdingu, co pozostaje mylące dla osób zatrudnionych, ale także osób trzecich;

3. przemieszanie sfer aktywności - jednoczesna aktywność wielu uczestników holdingu na tym samym polu (na przykład realizacja tej samej usługi dla tego samego kontrahenta);

4. „oszczędności” na świadczeniach pracowniczych lub obciążeniach publicznoprawnych w porównaniu do sytuacji, w której nie istniałaby wielość stosunków zatrudnienia - w posługiwaniu się tą okolicznością konieczna jest daleko idąca ostrożność. Nie chodzi bowiem o zakazywanie „optymalizacji" kosztów w tym zakresie, lecz wyeliminowanie zjawisk patologicznych, a zatem tych, co do których wchodzą w grę zachowania opisane w poprzednich punktach.

Propozycji tej nie traktuję jako zamkniętej i wyczerpującej. Z pewnością mogą w ramach wielości zatrudnienia pojawiać się także inne okoliczności świadczące o nadużywaniu odrębności uczestników zgrupowania.

Drugą grupą, w której pojawić się może nadużycie, są przypadki reorganizacji. Przykładem może tu być stan faktyczny sprawy zakończonej wyrokiem Sądu Najwyższego z dnia 18 września 2014 r., III PK 136/13. W sprawie tej doszło do przekazania zakładu pracy nowemu pracodawcy w trybie art. $23^{1}$ k.p. Spółka ta, po upływie okresu ochronnego z art. $241^{8} \S 1$ k.p., przeprowadziła restrukturyzację zatrudnienia (program dobrowolnych odejść), a potem doszło do ,powrotnego" transferu zakładu pracy do pierwotnego pracodawcy. W grupie obowiązywał pakiet socjalny zawierający gwarancje zatrudnienia na jednolitych zasadach dla wszystkich spółek. Gwarancje pakietowe nie zakazywały rozwiązywania stosun-

25 Ibidem, s. 20.

26 Zob. także A. Kurzych, Multiplikacja podmiotów zatrudniajacych a stosunki ubezpieczenia społecznego, [w:] Umowy cywilnoprawne w ubezpieczeniach społecznych, red. M. Szabłowska-Juckiewicz, M. Wałachowska, J. Wantoch-Rekowski, Warszawa 2015, s. 333 n. 
ków pracy za porozumieniem stron. Właśnie w tym trybie doszło do rozwiązania stosunku pracy z powódką, przy czym wiążąca się z rozwiązaniem odprawa wynosiła o połowę mniej niż odprawy oferowane w spółce matce (z której wydzielił się zakład i do której „powrócił”).

Sąd Najwyższy uznał, że w tej sytuacji dopuszczalne jest porównywanie warunków rozwiązania stosunku pracy w spółce-matce i spółce-córce. Sytuacja ta była, w jego ocenie, nadużyciem konstrukcji osobowości prawnej. Przypomniał bowiem, że w sprawie ustalono, iż wyodrębniony zakład (zakład remontowy) miał do wykonania tyle zadań, że dokonywanie zwolnień nie było racjonalne. Zakład nie miał także środków na finansowanie programu dobrowolnych odejść, które przekazywała na ten cel spółka dominująca. Także w kadrach spółki dominującej odbywały się czynności organizacyjne w ramach programu (zawieranie porozumień rozwiązujących).

Jakkolwiek Sąd Najwyższy nie posiłkował się treścią art. 8 k.p. (którego nie powołano w granicach skargi kasacyjnej, co ograniczało Sąd), uważam, że odwołanie się do koncepcji nadużycia osobowości prawnej jest oczywistym zarzutem nadużycia prawa. Podzielając w pełni treść rozstrzygnięcia, uważam, że bez tego stwierdzenia nie sposób dokonać wykładni art. $11^{2}$ k.p. w sposób, który uzasadniałby porównywanie warunków pracy u różnych pracodawców, nawet jeśli są oni zgrupowani w holdingu. Dopiero występujący w niniejszej sprawie element nadużycia prawa (transfer i retransfer obudowane innymi wskazanymi okolicznościami) umożliwiał przypisanie pracodawcy (spółce zależnej) nierównego traktowania.

Ponownie jak w wypadku równoległego zatrudnienia można, w ocenie autora niniejszych uwag, wskazać następujące, generalne, kryteria pozwalające dopatrywać się nadużyć związanych z transferem ${ }^{27}$ :

1. dokonywanie transferów w celu ograniczania działalności, a nie jej kontynuowania, w szczególności w celu dokonania zwolnień pracowniczych (w tym zwolnień grupowych); może się to wiązać z

2. dokonywaniem transferów „czasowych" - w celu dokonania zwolnień, a potem powrotnego przekazania zakładu pracy do pierwotnego pracodawcy; przy czym

3. w obu wymienionych przypadkach występuje przeważnie „oszczędność” na świadczeniach pracowniczych z tytułu rozwiązania stosunku pracy;

4. sztuczne dzielenie zakładu pracy na części, z których pewne podlegają transferowi, a inne - likwidacji, co ma uzasadniać prawo rozwiązania stosunku pracy z tego ostatniego powodu; celem w tym wypadku nie jest wyłącznie zaoszczędzenie na kosztach rozwiązania stosunku pracy, lecz przede wszystkim sama możliwość dokonania takiej czynności.

27 Ibidem, s. 22. 


\section{WNIOSKI}

1. Grupowanie przedsiębiorstw w formie holdingowej znajduje wiele uzasadnień o charakterze ekonomicznym, organizacyjnym i prawnym. Zjawiska tego nie sposób - samego z siebie — traktować jako nadużycie swobody gospodarczej.

2. Do nadużyć może jednak dochodzić w toku wykonywania przez podmioty zgrupowane ich uprawnien. Pozwala to na kwestionowanie poszczególnych, negatywnie ocenianych, działań, lecz nie generalnego faktu istnienia zgrupowania.

3. Z perspektywy indywidualnego prawa pracy zasadniczym problemem jest korzystanie przez pracodawców zgrupowanych z zasady swobody umów w aspekcie podmiotowym (swoboda doboru kontrahenta), co skutkuje wielością relacji zatrudnienia jednej osoby z różnymi uczestnikami grupy oraz dokonywaniem transferów między podmiotami zgrupowanymi, co uprawnia ich do modyfikacji warunków zatrudnienia.

4. Nie da się w istniejących normach prawnych, w szczególności w art. 3 k.p., odnaleźć podstaw do formuły pracodawcy wielopodmiotowego, którym byłby cały holding lub jego niektórzy uczestnicy.

5. De lege lata można niwelować tylko pojedyncze skutki negatywnie ocenianych zachowań w ramach grupy spółek, a zatem nie wszystkie niepożądane konsekwencje ich funkcjonowania z perspektywy osoby zatrudnionej. Przeciwdziałać można zachowaniom będącym nadużyciem formy spółki, dla których ogólną ramę może tworzyć art. 8 k.p., choć w szczegółowych przypadkach wykorzystać można konkretne, istniejące, instrumenty prawa pracy, zamiast odwoływać się do nadużycia prawa.

6. Usuwanie tych skutków polega co do zasady na przypisaniu pracodawcy zachowań przejawianych przez podmioty z grupy lub ich funkcjonariuszy. Skutki tych działań ponosi więc pracodawca tak, jakby były one realizowane w istniejącym stosunku pracy.

\section{HOLDING AS AN EMPLOYER. DILEMMAS OF INDIVIDUAL LABOUR LAW IN A GROUP OF COMPANIES}

\section{Summary}

The growing role of groups of companies in modern economy challenges traditional concepts of an employer. Since a holding de lege lata may not be treated as an employer, we need to find other solutions for problems arising in multi-entity structures. Existing regulations, with direct or indirect support of art. 8 of the Labour Code, allow to minimize some aspects of abuse of legal personality, such as multiple employment and unfair restructuring. They allow to treat various activities of different members of the group as if they were activities of the sole employer.

Keywords: employer, holding, multiple employment 


\section{BIBLIOGRAFIA}

Czarnecki P., Odpowiedzialność pracodawcy a rozwój struktur holdingowych, Warszawa 2014.

Frąckowiak J., Jednostka organizacyjna jako substrat osoby prawnej i ustawowej, [w:] Rozprawy prawnicze. Księga pamiatkowa prof. Maksymiliana Pazdana, red. L. Ogiegło, W. Popiołek, M. Szpunar, Kraków 2005.

Gersdorf M., Jeszcze w sprawie sporu o pojęcie pracodawcy, PiZS 1997, nr 2.

Hajn Z., [w:] System prawa pracy, t. 2, red. G. Goździewicz, Warszawa 2017.

Hajn Z., Pojęcie pracodawcy po nowelizacji Kodeksu pracy, cz. I, PiZS 1997, nr 5.

Jończyk J., Sytuacja zaktadu pracy w kombinacie w świetle przepisów Kodeksu pracy, [w:] Sytuacja prawna zakładów kombinatów, red. A. Klein, Wrocław 1982.

Kaczyński L., W sprawie jednostki organizacyjnej jako pracodawcy, PiZS 1998, nr 5.

Klein A., Sytuacja prawna zakładów kombinatów obrocie uspołecznionym, [w:] Sytuacja prawna zakładów kombinatów, red. A. Klein, Wrocław 1982.

Kubot Z., Odcinkowa zdolność pracodawcza spółki dominującej w grupie kapitałowej, PiZS 2014, nr 9.

Kubot Z., Rola spótki dominującej w sporze zbiorowym spótki zależnej, cz. I, PiZS 2014, nr 10; cz. II, PiZS 2014, nr 12.

Kubot Z., Wielkie organizacje gospodarcze a zakład pracy, [w:] Pracownicy i pracodawcy. Materiały XVI Zimowej Szkoły Prawa Pracy, red. W. Sanetra, Wrocław 1989.

Kurzych A., Multiplikacja podmiotów zatrudniajacych a stosunki ubezpieczenia społecznego, [w:] Umowy cywilnoprawne w ubezpieczeniach społecznych, red. M. Szabłowska-Juckiewicz, M. Wałachowska, J. Wantoch-Rekowski, Warszawa 2015.

Lewandowski H., Problemy prawa pracy zwiazane z restrukturyzacja przedsiębiorstwa, [w:] Człowiek, obywatel, pracownik. Księga jubileuszowa poświęcona profesor Urszuli Jackowiak, red. J. Stelina, A. Wypych-Żywicka, Gdańsk 2007.

Mariański A., Podatek dochodowy od osób prawnych. Komentarz, Warszawa 2012.

Okolski J., Opalski W., Uwagi na temat możliwości tworzenia organizacji koncernowych w Polsce, PUG 1987, nr 6.

Pisarczyk Ł., Ryzyko pracodawcy, Warszawa 2009.

Raczkowski M., Grupa spótek (holding) jako pracodawca, PiZS 2016, nr 7.

Raczkowski M., Pomijanie prawnej odrębności członków holdingu w indywidualnym prawie pracy, PiZS 2016, nr 7.

Raczkowski M., Powiazania kapitałowe pracodawcy a stosunek pracy, PiP 2009, nr 3.

Szumański A., [w:] S. Sołtysiński et al., Kodeks spółek handlowych. Komentarz, Warszawa 2004. 